\title{
THREE BONAPARTE'S GULL NESTS AT SPRUCE LAKE, SK
}

MARY I. HOUSTON and C. STUART HOUSTON, 863 University Drive, Saskatoon, SK S7N 0J8

Our first sighting of a Bonaparte's Gull nest occurred on June 19, 2004, during the bus tour to Spruce Lake during Nature Saskatchewan's Spring Meet. Our entire party observed three pairs nesting, each in a small, solitary spruce, beside the lakeside trail on the north shore of Spruce Lake, 14 $\mathrm{km}$ south of St. Walburg. Stuart and I stopped again on June 20 and paid a third visit on July 18.

The first nest, in a spruce right on the bank of the lake, was $2 \mathrm{~m}$ above the lake level. An adult sat tight on June 19, but rose up to display at least two downy young on June 20 . On July 18, one adult sat at the top of the spruce, then both adults dove at us.

The second nest, also in a spruce right on the bank, was about $60 \mathrm{~m}$ along the shore from the first nest (by GPS calculations) and 2.7 $m$ above the lake level. The adult sat tight on June 19, but the following day rose up sufficiently to reveal three young. Both adults dove at us when we returned on July 18.

The third nest was in a spruce 1 or $2 \mathrm{~m}$ from the lake edge, and another $225 \mathrm{~m}$ along the shore from the second nest. It was $3.5 \mathrm{~m}$

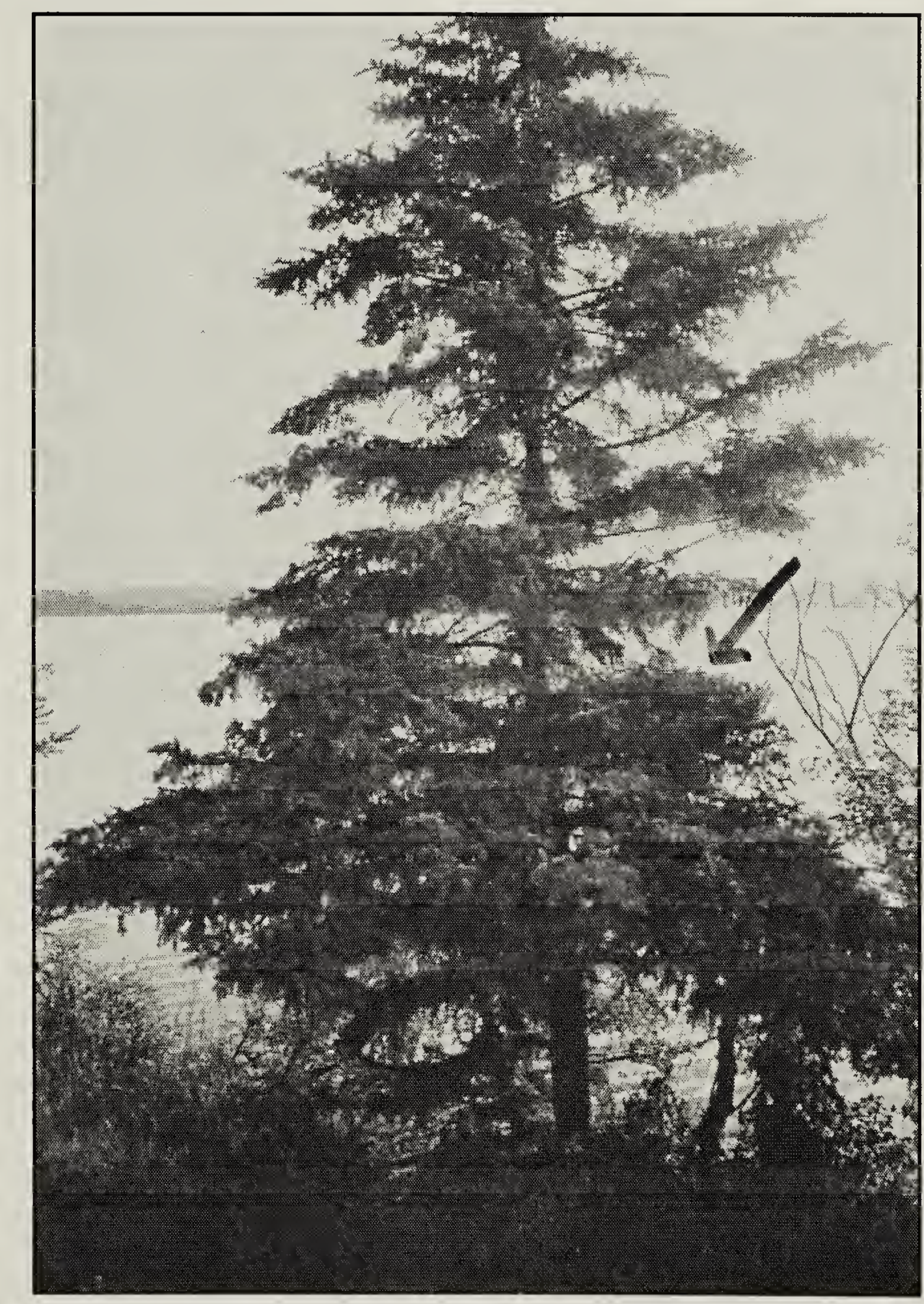

Location of Bonaparte's Gull nest \# 1 at Spruce Lake, on 19 June 2004 
above ground, too high to see into without disturbing the adult. On July 18, the nest had apparently fallen, but two adults divebombed us.

No young were visible on July 18 , but the behaviour of the all three pairs of adults suggested persistent territorial defense or possibly one or more flightless young hiding somewhere in the vicinity. The commonest clutch size is three eggs. Young are said to remain in the nest for two to seven days after hatching, but no data are available concerning the age at first flight. ${ }^{1}$

We thought it remarkable that the first and second nests were in the only two suitable spruce on that part of the lakeshore, and closer together than typical Bonaparte's Gull nests. Near Churchill, Manitoba, "individual territories are large and inter-nest distances are usually $>500 \mathrm{~m} .{ }^{.2}$

Bonaparte's Gull is the only gull "that regularly, indeed almost always, nests in trees." ' As with most rules, there are exceptions; the best-documented marsh nesting of this species is for "Lamotte's Swamp" near Jackfish Lake, Saskatchewan, in 1931-1935 and again in 1955 and 1956. ${ }^{3}$

1. BURGER, J., and M. GOCHFELD. 2002. Bonaparte's Gull (Lainis philadelphia). In The Birds of North America, no. 634 (A. Poole and F. Gill, eds.). The Birds of North America, Philadelphia, PA.

2. JEHL, J.R., Jr. 2004. Birdlife of the Churchill Region: Status, History, Biology. Trafford Publishing, Victoria, BC.

3. SYMONS, R.D. 1968. Atypical nesting of Bonaparte's Gull in Saskatchewan. Blue Jay 26:7074.

\section{SURPRISE EFFECT}

Warm July afternoon

walking back to the car

while the dog explores afar

casting my eyes downward

blinking in the bright light

suddenly a swift shadow

flits across the path

look up in surprise

as a large dragonfly skims past

on gauzy transparent wings

glad to be reminded that

even such a fragile form

casts so solid a shadow. 